\title{
Penerapan Teknologi Pengindraan Jauh untuk Identifikasi Padang Penggembalaan Alam di Kecamatan Pandawai, Kabupaten Sumba Timur
}

\author{
Bogarth K. Watuwaya ${ }^{1 *}$, Herlistin Mooy ${ }^{1}$ \\ ${ }^{1}$ Sekolah Pertanian Pembangunan Negeri Kupang - BPPSDMP Kementan \\ *Corresponding author: bogarthw@gmail.com
}

\begin{abstract}
Abstrak
Penelitian ini bertujuan untuk mengidentifikasi padang pengembalaan alam di Kecamatan Pandawai, Kabupaten Sumba Timur, Propinsi Nusa Tenggara Timur. Kecamatan ini memiliki tingkat populasi ternak ruminansia terbesar dan wilayah padang rumput terluas di Kabupaten Sumba Timur. Untuk menduga kapasitas tampung padang rumput perlu dilakukan suatu rangkaian tindakan identifikasi untuk memperoleh data luasan, letak dan keadaan topografi. Identifikasi secara manual sangat membutuhkan waktu dan tenaga kerja, melalui pendekatan teknologi pengindraan jauh akan mempersingkat waktu, tenaga serta meningkatkan presisinya. Metode yang digunakan adalah klasifikasi terbimbing dengan alogaritma kemungkinan maksimum (maximum likelihood) citra Sentinel-2A. metode confusion matrix digunakan untuk menguji keakurasian klasifikasi.. Klasifikasi kelas kelerengan menggunakan data digital elevation model dari DEMNAS. Hasil penelitian menunjukkan bahwa luas area non padang rumput sebesar 6.568 hektar, area padang rumput seluas 39.860 hektar. Hasil uji akurasi confusion matrix sebesar 91, $72 \%$. Kelerengan terbagi dalam lima kelas, dimana luas area kelas 0 - 8\% (31.691 Ha), 8-15\% (1.433 Ha), $15-25 \%$ (2.203 Ha), 25-40\% (362 Ha) dan >40\% (10.888 Ha).
\end{abstract}

Kata kunci : Padang rumput, Klasifikasi terbimbing, Kemungkinan maksimum, DEM

\section{Abstract}

This study aimed to identify native grasslands areas in Pandawai District, East Sumba Regency, East Nusa Tenggara Province. This sub-district has the largest population of ruminants and the largest area of grassland in East Sumba Regency. To estimate the carrying capacity of the grasslands, it is necessary to carry out a series of identification study to obtain the data on the area, location and also topography. Manual identification is time consume and labor intensive, through remote sensing technology approach, it will shorten the time, effort and also increase the accuration. The methodology used is a supervised classification with the maximum likelihood algorithm of Sentinel-2A imagery. The confusion matrix method is used to test the accuracy of the classification. Slope class classification used a digital elevation model data from DEMNAS. The results showed that the non-grassland area was 6,568 hectares, and the grassland area was 39,860 hectares. The results of the confusion matrix accuracy test are 91, 72\%. Slopes classes are divided into five, where the class area is $0-8 \%(31,691 \mathrm{Ha}), 8-15 \%(1,433 \mathrm{Ha}), 15-25 \%(2,203$ $\mathrm{Ha}), 25-40 \%(362 \mathrm{Ha})$ and $>40 \%(10,888 \mathrm{Ha})$.

Key words : Grasslands, Supervised Classification, Maximum Likelihood, DEM 
Prosiding Seminar Nasional Pembangunan dan Pendidikan Vokasi Pertanian Politeknik Pembangunan Pertanian Manokwari, 14 November 2020

e ISSN : 2774-1982

\section{PENDAHULUAN}

Sumba Timur merupakan salah satu kabupaten di Nusa Tenggara Timur yang memiliki sumberdaya alam berupa padang rumput guna mendukung dikembangkannya usaha peternakan sapi potong, hal ini terlihat dari kepadatan ternak, kepadatan wilayah, kepadatan usaha tani serta keunggulan wilayah (Watuwaya et al., 2020). Kecamatan Pandawai dengan luas wilayah 41.260 hektar, merupakan kecamatan dengan populasi ternak terbanyak di Kabupaten Sumba Timur. Merujuk pada data statistik, populasi ternak sapi potong Sumba Ongole (SO) berjumlah 51.811 ekor, Kerbau 37.937 ekor, Kuda 32.903 ekor, Kambing dan Domba 57.852 ekor (BPS, 2020).

Padang rumput alam merupakan sebuah ekosistem yang merupakan sumber pakan utama bagi ternak yang digembalakan secara bebas di padang rumput menurut kebutuhannya dalam waktu tertentu (Sutaryono and Patridge, 2002; Bengston et al., 2019). Kemiringan lahan sangat berpengaruh pada bentang padang rumput, dimana kemiringan diatas 15 derajat dapat sangat berbahaya bagi ternak yang merumput diatasnya (Dirjen Perluasan dan Pengolahan Lahan, 2014). Beberapa kurun waktu terakhir terjadi degradasi luas padang rumput, hal ini terjadi sebagai akibat dari peristiwa alam maupun karena aktivitas manusia. Peningkatan populasi penduduk dan pembangunan di sektor pertanian dan industri telah menyebabkan terjadinya alih fungsi lahan padang rumput menjadi areal peruntukan lain, seperti lahan pertanian, jaringan irigasi, pemukiman maupun peruntukan lainnya (Liu et al., 2019; Cao et al., 2019).

Sebagai sumber pakan alami, padang rumput alam memiliki kapasitas tampung bagi ternak yang terbatas. Kapasitas tampung ini sangat bervariasi, bergantung pada komposisi botani serta luas padang rumput tersebut (Sutaryono dan Partridge, 2002). Untuk mendapatkan letak dan ukuran yang presisi suatu padang rumput dimuka bumi tentulah bukan perkara yang mudah bila masih dilakukan secara manual melalui metode survei yang melelahkan, pengukuran presisi di lapang akan memakan banyak waktu, anggaran dan tenaga. Semenjak teknologi pengindraan jauh dan sistem informasi geografis dikembangkan, metode pengukuran konvensional seperti ini sudah jarang digunakan. Pengindraan jauh merupakan ilmu dan seni dalam memperoleh informasi tentang objek, wilayah, atau gejala dengan cara menganalisa data yang diperoleh dengan menggunakan alat tanpa kontak langsung terhadap objek, wilayah, atau gejala yang dikaji (Lilesand dan Kiefer, 2007; Tiscornia et al., 2019). 
Prosiding Seminar Nasional Pembangunan dan Pendidikan Vokasi Pertanian Politeknik Pembangunan Pertanian Manokwari, 14 November 2020

e ISSN : 2774-1982

\section{METODE}

Penelitian ini merupakan penelitian survey kuantitatif dengan menganalisa datadata sekunder yang diperoleh dari institusi terkait. Penelitian dilakukan di LAPAN Parepare, Sulawesi Selatan dan di Kecamatan Pandawai, Kabupaten Sumba Timur, Propinsi Nusa Tenggara Timur. Penelitian dilakukan pada puncak musim kemarau awal bulan Oktober 2020. Pemilihan waktu dengan maksud memudahkan dalam interpretasi areal padang rumput dan non padang rumput.
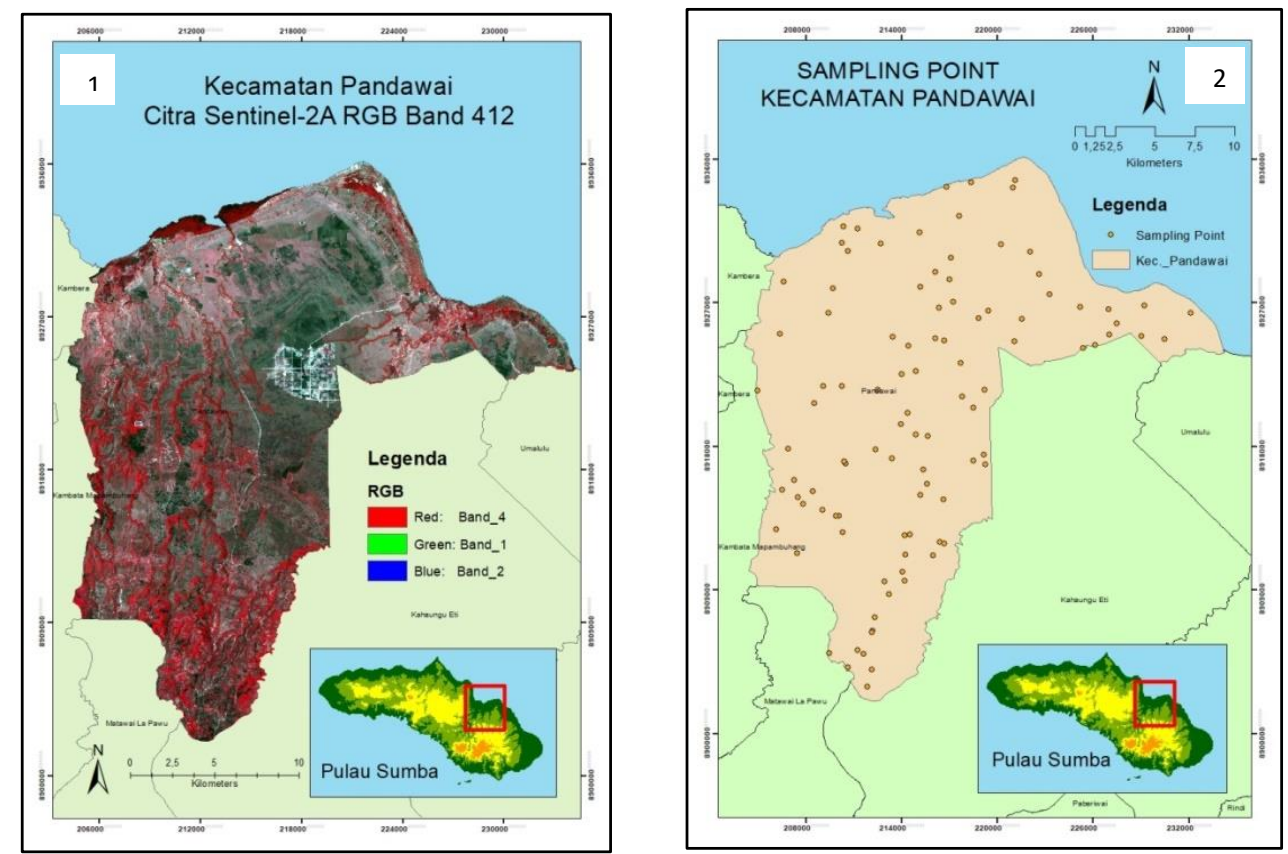

Gambar 1 Penampakan Citra Sentinel-2A Kecamatan Pandawai dengan Band RGB 412 untuk memperjelas rona dan warna vegetasi dalam tutupan lahan. Gambar 2 Sebaran titik random sampling yang digunakan sebagai uji akurasi klasifikasi (confusion matrix).

Penelitian ini menggunakan metode spasial untuk mengidentifikasi padang rumput. Data Citra satelit yang digunakan adalah Sentinel-2A yang diunduh pada situs https://scihub.copernicus.eu. Sentinel-2A merupakan satelit observasi bumi milik European Space Agency (ESA). Satelit ini aktif pada program Copernicus. Dilengkapi dengan instrumen multispektral dengan 13 saluran spektral dari saluran cahaya tampak, inframerah dekat serta gelombang pendek inframerah. Sentinel-2A memiliki resolusi 10 meter untuk band cahaya tampak dan inframerah dekat, 20 dan 60 meter untuk band gelombang inframerah dekat dan gelombang pendek inframerah (ESA, 2020)

\section{Klasifikasi Terbimbing Maximum Likelihood}

Dalam penelitian ini dilakukan identifikasi objek dengan interpretasi citra secara visual untuk memperoleh tutupan lahan padang rumput dan non padang rumput. Berbagai 
Prosiding Seminar Nasional Pembangunan dan Pendidikan Vokasi Pertanian Politeknik Pembangunan Pertanian Manokwari, 14 November 2020

e ISSN : 2774-1982

karakteristik untuk mengenali objek pada citra tersebut meliputi rona dan warna, bentuk, ukuran, tekstur, pola, bayangan serta asosiasi. Alogaritma klasifikasi yang digunakan adalah dengan metode klasifikasi terbimbing (supervised classification) menggunakan alogartima kemungkinan maksimum (maximum likelihood). Maximum likelihood adalah alogartima untuk mendapatkan kemiripan maksimum dari suatu vektor yang belum terklasifikasi berdasarkan kelas yang telah ditentukan (Newman, 2003; Ahmad, 2012). Alogartima ini menggunakan persamaan Bayesian (1). Alogaritma ini dipilih karena persamaan alogaritma ini lebih mapan dalam uji statistik. Analisis klasifikasi citra Sentinel-2A ini menggunakan software ENVI 5.

$$
\mathrm{D}=\operatorname{In}(\mathrm{ac})-[0.5 \ln (\operatorname{lcovcl})]-[0.5(\mathrm{X}-\mathrm{Mc}) \mathrm{T}(\operatorname{covc}-1)(\mathrm{X}-\mathrm{Mc})]
$$

dimana :

$$
\begin{array}{ll}
\mathrm{D} & =\text { bobot kemiripan (weighted likelihood) } \\
\mathrm{X} & \text { = vektor yang belum terklasifikasi } \\
\mathrm{Mc} & \text { = kelas yang telah diketahui }
\end{array}
$$

\section{Pengujian Tingkat Akurasi}

Pengujian akurasi dilakukan untuk mengetahui tingkat ketepatan hasil klasifikasi yang telah dilakukan. Pengujian akurasi menggunakan metode confusion matrix, dikenal juga sebagai tabel kontigensi atau tabel kesalahan. Tabel ini digunakan untuk mengukur hubungan antara dua variabel kategorik dimana tabel ini merangkum frekuensi bersama dari observasi pada setiap kategori variabel (Ahmad, 2012; Luque et al., 2019) Persamaan yang digunakan untuk mengukur overall accuracy adalah sebagai berikut

$$
O A=\frac{\sum_{i=1}^{r} x_{i i}}{N}
$$

dimana

$$
\begin{array}{ll}
\mathrm{OA} & =\text { Overall Accuracy } \\
\mathrm{N} & =\text { Jumlah total piksel } \\
\mathrm{x}_{\mathrm{ii}} & =\text { Nilai piksel dalam bari i dan kolom ke } \mathrm{i} \\
\mathrm{r} & =\text { jumlah kolom atau baris pada confusion matrix }
\end{array}
$$

\section{Digital Elevation Model (DEM)}

Model elevasi digital atau (DEM) adalah kumpulan data penting untuk banyak analisa fitur lahan. Model elevasi digital adalah grid raster yang mereferensikan titik awal dari permukaan bumi. Pemodelan ini memungkinkan untuk mengeleminasi objek di permukaan bumi seperti objek gedung, tanaman maupun penggunaan lain. Model DEM merupakan model 3 dimensi dengan permukaan yang halus (Hutchinson and Gallant, 
Prosiding Seminar Nasional Pembangunan dan Pendidikan Vokasi Pertanian

Politeknik Pembangunan Pertanian Manokwari, 14 November 2020

e ISSN : 2774-1982

2020; Ibrahim et al., 2020). Data DEM yang digunakan diunduh dari situs DEMNAS tides.big.go.id. Pada penelitian ini menggunakan data DEMNAS_2106-12_v1.0, DEMNAS_2106-14_v1.0 dan DEMNAS_2106-23_v1.0 yang diunduh dari situs Badan Informasi dan Geospasial. Analisis DEM menggunakan software GlobalMapper versi 20 dan ArcMap versi 10.5.

\section{HASIL DAN PEMBAHASAN}

\section{Identifikasi Padang penggembalaan}

Secara harafiah padang rumput merupakan areal untuk menggembalakan ternak ruminansia dengan tatalaksana pemeliharaan ternak dilepas bebas (grazing / diliarkan) untuk merumput dalam upaya mendukung efisiensi tenaga kerja dalam budidaya ternak. Pada sistem ini ternak sengaja diumbar pada lahan tertentu agar dapat bebas memilih hijauan yang dibutuhkan (sistem cafetarian) sehingga dapat memacu pertumbuhan ternak tersebut (Sutaryono and Partridge, 2002; Dirjen Perluasan dan Pengolahan lahan, 2014).

Padang penggembalaan dapat diklasifikasikan menjadi empat golongan utama, yakni: (a) Padang penggembalaan alam, (b) Padang penggembalaan permanen yang sudah diperbaiki, (c) Padang penggembalaan buatan (temporer), dan (d) Padang penggembalaan dengan irigasi. Vegetasi yang tumbuh pada padang penggembalaan terdiri atas rumput-rumputan, kacang-kacangan, atau campuran keduanya (McIllroy, 1976; Ren et al., 2008; Dirjen Perluasan dan Pengolahan lahan, 2014).

Perkembangan luasan areal padang rumput mengalami penurunan karena beberapa hal, diataranya karena (a) terdesaknya padang penggembalaan akibat persaingan dengan penggunaan lahan pertanian dan (b) kerusakan akibat tanaman pengganggu (gulma). Peningkatan populasi penduduk serta meningkatnya kesejahteraan merupakan alasa utama dalam alih fungsi lahan, sedangkan tanaman pengganggu (gulma) yang penyebarannya masif saat ini adalah rumput bunga putih (Chromolaena odorata) atau kirinyu atau rumba tai kabala dalam bahasa lokal Sumba Timur (Nulik dan Bamualim, 1998). Permasalahan - permasalahan tersebut menjadikan identifikasian padang rumput terasa penting.

Kombinasi band RGB 412 atau RGB 142 menghasilkan kenampakan warna objek yang tidak sebenarnya (false color). Kombinasi band RGB 412 bermakna bahwa band 4 yang merupakan band pada panjang gelombang inframerah dekat diinput pada kanal warna merah, band 1 yang merupakan band warna merah diinput pada kanal warna 
Prosiding Seminar Nasional Pembangunan dan Pendidikan Vokasi Pertanian Politeknik Pembangunan Pertanian Manokwari, 14 November 2020

e ISSN : 2774-1982

hijau, dan band 2 yang merupakan band warna hijau diinput pada kanal warna biru, sehingga menghasilkan kenampakan data citra satelit dominasi warna merah semu.

Dengan kombinasi band tertentu objek-objek vegetasi secara umum akan berwarna merah, seperti rumput berwarna merah muda cerah hingga magenta, pepohonan lebat akan berwarna merah agak gelap, sedangkan objek lain seperti air jernih berwarna biru tua hingga kehitaman, air keruh berwarna biru muda keputihan, tanah bewarna cokelat atau cokelat merah menjadi terlihat kehijauan. Demikian pula dengan kombinasi band RGB 142 akan menghasilkan data citra satelit dengan dominasi warna hijau semu.

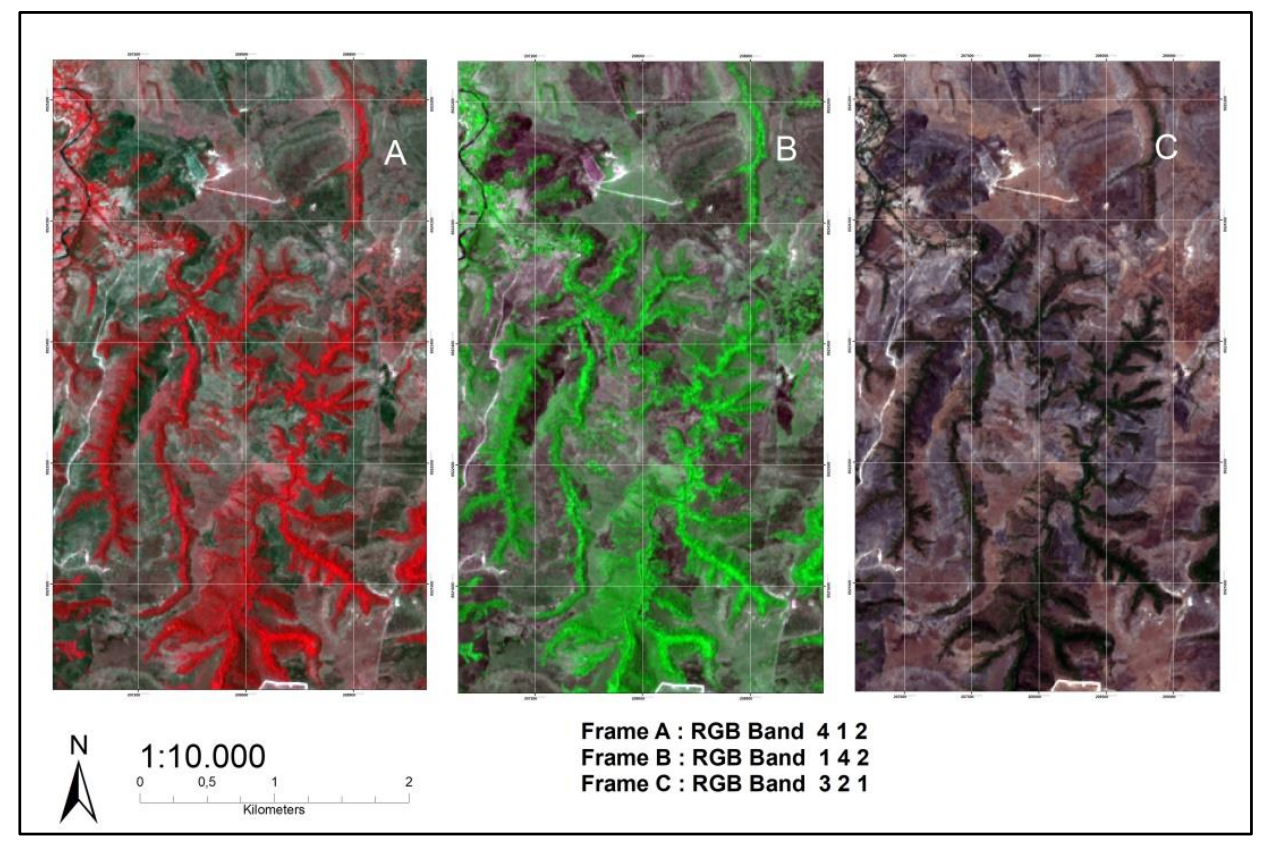

Gambar 3 Identifikasi padang penggembalaan dengan menggunakan citra Sentinel-2A di Kecamatan Pandawai menggunakan metode visual dan metode digital untuk membedakan tutupan lahan (land cover) padang penggembalaan dan tutupan lahan bukan padang penggembalaan. Band RGB 412 digunakan untuk memudahkan pembedaan antara vegetasi dari objek tutupan lahan lainnya. Untuk mengetahui kenampakan padang rumput berdasarkan interpretasi, maka dilakukan pengamatan pada citra satelit resolusi sangat tinggi SPOT 5. Melalui pengamatan diperoleh petunjuk padang rumput dengan ciri warna, bentuk dan ukuran.

Warna merah semu dan hijau semu yang terlihat pada objek-objek vegetasi terjadi karena vegetasi lebih kuat memantulkan gelombang elektromagnetik pada panjang gelombang inframerah dekat (near infrared), dan oleh karena itu warna vegetasi menjadi berwarna merah semu pada data citra satelit dengan kombinasi band RGB 412, dan berwarna hijau semu pada data citra satelit dengan kombinasi band RGB 142. 
Penggunaan kombinasi band yang tepat akan memudahkan interpreter melakukan identifikasi terhadap objek-objek yang menjadi fokus perhatian. Warna natural (true color) memberikan kenampakan warna objek sesuai dengan warna yang terlihat oleh mata manusia normal, seperti objek vegetasi yang berwarna hijau, tanah yang berwarna merah kecoklat-coklatan, atap rumah berwarna cokelat, dan badan air berwarna biru (gambar 3).

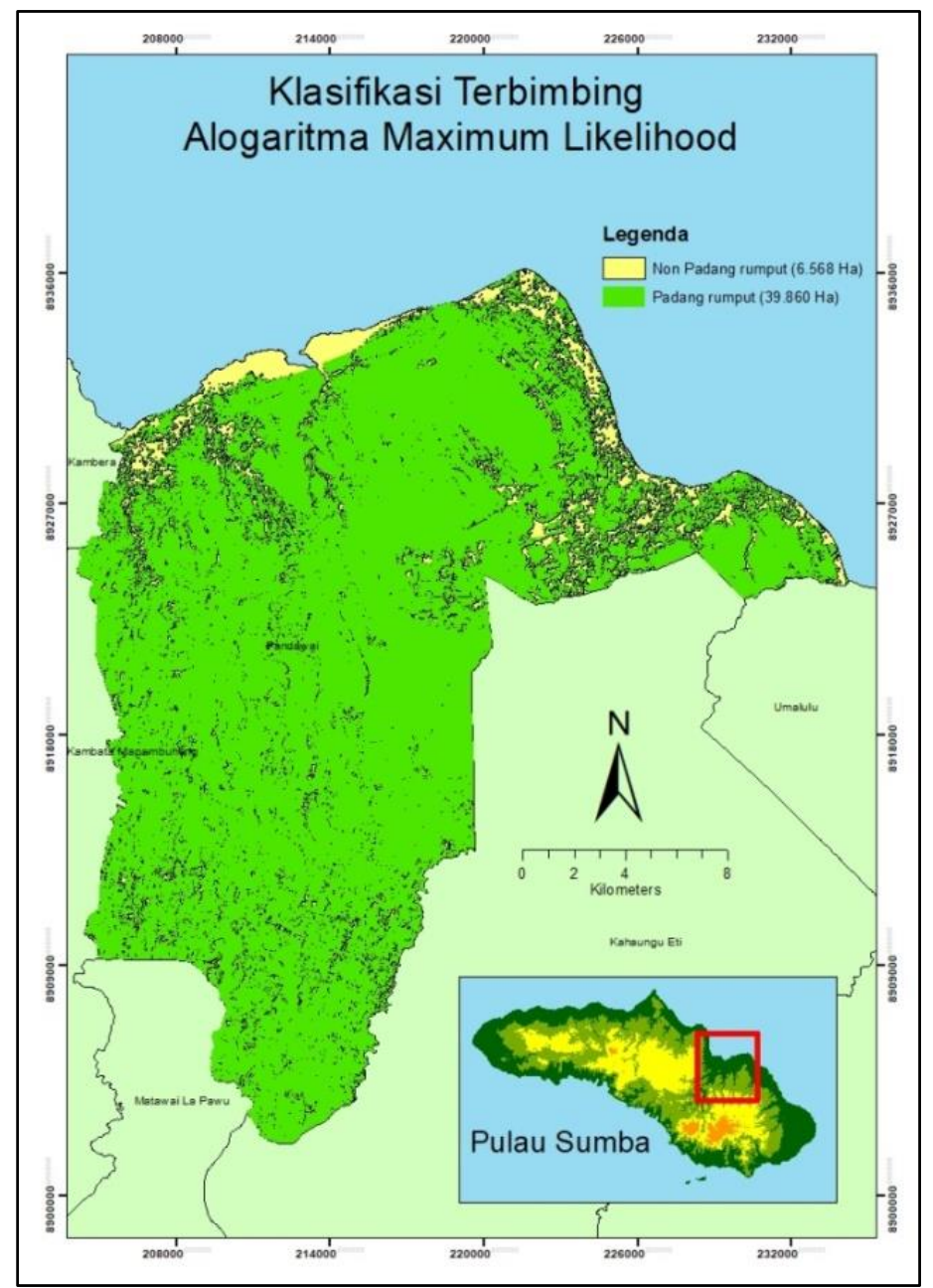

Gambar 4 Hasil Klasifikasi terbimbing dengan alogaritma Maximum Likelihood

Berdasarkan petunjuk interpretasi yang diperoleh dari pengamatan pada citra SPOT 5, selanjutnya dilakukan deliniasi secara manual pada citra Sentinel-2A. Selanjutnya hasil interpretasi secara visual digunakan sebagai rujukan saat uji akurasi confussion matrix. Selain secara visual, uji akurasi secara nyata juga dilakukan langsung di lapangan (ground truth) pada titik - titik koordinat yang telah diacak secara random. Pembuatan training sampel dalam jumlah yang banyak akan semakin meningkatkan 
Prosiding Seminar Nasional Pembangunan dan Pendidikan Vokasi Pertanian Politeknik Pembangunan Pertanian Manokwari, 14 November 2020

e ISSN : 2774-1982

keakuratan data yang diperoleh serta dapat mewakili tutupan lahan pada citra. Interpretasi secara manual akan membutuhkan waktu yang lama apabila luasan wilayah yang diinterpretasi semakin luas.

Klasifikasi tutupan lahan menggunakan 6 kelas yang telah dipersempit, yaitu kelas badan air, areal pertanian, pohon / hutan, semak belukar, lahan terbuka, dan lahan terbangun. Hasil pengklasifikasian ini selanjutnya dilakukan proses reklasifikasi dengan menggabungkan kelas badan air, areal pertanian, pohon/hutan dan lahan terbangun sebagai kelas non padang rumput sedangkan kelas lahan terbuka dan semak belukar menjadi area padang rumput. Reklasifikasi menunjukkan bahwa lahan seluas 6.568 hektar merupakan non padang rumput, sedangkan kawasan seluas 39.860 hektar merupakan area padang rumput (gambar 4).

Akurasi ketelitian hasil klasifikasi selanjutnya diuji menggunakan tabel confussion matrix. Hasil klasifikasi menunjukkan bahwa nilai overall accuracy dari klasifikasi terbimbing maximum likelihood terhadap klasifikasi visual dan ground truth adalah sebesar $91,72 \%$. Nilai total overall accuracy yang diperoleh telah melampaui nilai standar tingkat ketelitian klasifikasi minimum dengan pendekatan pengindraan jauh yang dikeluarkan oleh badan survey geology Amerika Serikat USGS (United Stated Geology Survey) yaitu tidak boleh kurang dari $85 \%$.

Tabel 1. Akurasi klasifikasi confussion matrix

\begin{tabular}{|c|c|c|c|c|c|c|c|c|c|}
\hline \multicolumn{8}{|c|}{ Penentuan tipe Kelas } & \multirow{2}{*}{$\begin{array}{l}\text { Overall } \\
\text { accuracy } \\
(\%)\end{array}$} & \multirow{2}{*}{$\begin{array}{l}\text { Analysis } \\
\text { of } \\
\text { Accuracy }\end{array}$} \\
\hline & $\begin{array}{l}\text { Pohon/ } \\
\text { hutan }\end{array}$ & $\begin{array}{c}\text { Areal } \\
\text { Pertanian }\end{array}$ & Semak & $\begin{array}{c}\text { Area } \\
\text { terbangun }\end{array}$ & $\begin{array}{l}\text { Lahan } \\
\text { terbuka }\end{array}$ & $\begin{array}{l}\text { Badan } \\
\text { air }\end{array}$ & Total & & \\
\hline Pohon / hutan & 60 & 2 & 1 & 0 & 0 & 0 & 63 & & 91.95 \\
\hline Areal Pertanian & 2 & 53 & 2 & 0 & 0 & 1 & 58 & & 92.98 \\
\hline Semak & 10 & 2 & 46 & 0 & 0 & 4 & 62 & & 73.02 \\
\hline Area terbangun & 0 & 0 & 0 & 31 & 1 & 0 & 32 & & 96.88 \\
\hline Lahan terbuka & 0 & 0 & 0 & 1 & 85 & 0 & 86 & & 98.84 \\
\hline Badan air & 0 & 0 & 1 & 0 & 0 & 24 & 25 & & 96.00 \\
\hline Total & 72 & 57 & 50 & 32 & 86 & 29 & 326 & 91.72 & \\
\hline
\end{tabular}

Tingkat ketelitian tertinggi diperoleh pada kelas lahan terbuka (padang rumput) $98,84 \%$, sedangkan nilai akurasi terendah pada kelas semak $(73,02 \%)$. Hal ini bisa terjadi karena saat pelaksanaan interpretasi, kelas lahan terbuka lebih mudah untuk dibedakan dengan objek lain yang berada disekitarnya namun semak belukar lebih sulit bila dibandingkan dengan kelas pohon/ hutan. Kesalahan ini biasa terjadi karena nilai reflektan pada suatu piksel yang hampir sama antara beberapa buah objek, pada kasus ini adalah pohon dan semak. Kesalahan interpretasi nilai reflektan ini menyebabkan proses 
Prosiding Seminar Nasional Pembangunan dan Pendidikan Vokasi Pertanian

Politeknik Pembangunan Pertanian Manokwari, 14 November 2020

e ISSN : 2774-1982

klasifikasi tidak berjalan dengan baik. Kemungkinan lain kesalahan ini bisa terjadi adalah karena kesalahan dalam menentukan training sampel (heterogen). Pemilihan band yang tepat dapat meminimalkan kesalahan interpretasi, sebab setiap objek memiliki kepekaan yang berbeda terhadap panjang gelombang tertentu.

\section{Kelerengan Padang Penggembalaan}

Kelerengan (slope) suatu permukaan lahan sangat menentukan arah kebijakan yang akan diambil. Penentuan mengenai nilai dan variabel kelas lereng dalam penentuan lahan budidaya dan non budidaya didapat dari tingkatan kelas kelerengan lahan itu sendiri. Berdasarkan SK Menteri Pertanian No.837/KPTS/UM/11/1980 dan No. 683/KPTS/UM/8/1981 adalah sebagai berikut

Tabel 2. Kelas Kelerengan Lahan

\begin{tabular}{ccll}
\hline Kelas lereng & Sudut lereng & \multicolumn{1}{r}{ Deskripsi } & Nilai \\
\hline 1 & $0-8 \%$ & Datar & 20 \\
2 & $8-15 \%$ & Landai & 40 \\
3 & $15-25 \%$ & Agak curam & 60 \\
4 & $25-40 \%$ & Curam & 80 \\
5 & $>40 \%$ & Sangat curam & 100 \\
\hline
\end{tabular}

Hasil pengolahan data DEM untuk ketinggian tempat diperoleh bahwa pada Kecamatan Pandawai bagian Selatan kecamatan ini berupa daerah berbukit dengan ketinggian tempat tertinggi $255 \mathrm{~m}$ dpl. Di bagian Selatan kecamatan merupakan daerah pesisir yang langsung berbatasan dengan laut (gambar 5). Untuk kelas kelerengan, wilayah Kecamatan Pandawai didomonasi oleh kelas kelerengan $0-8 \%$ (datar) seluas $31.691 \mathrm{Ha}, 8$-15\% (landai) seluas $1.433 \mathrm{Ha}$. Total kedua wilayah ini seluas $5.524 \mathrm{Ha}$ merupakan wilayah dengan kelerengan dibawah 15\%. Areal ini merupakan areal yang ideal untuk dikembangkan usaha budidaya ternak, terlebih bagi pengembangan padang penggembalaan. Lahan dengan kelerengan 15 - $40 \%$ (agak curam - sangat curam) seluas $2.385 \mathrm{Ha}$ (gambar 6). 

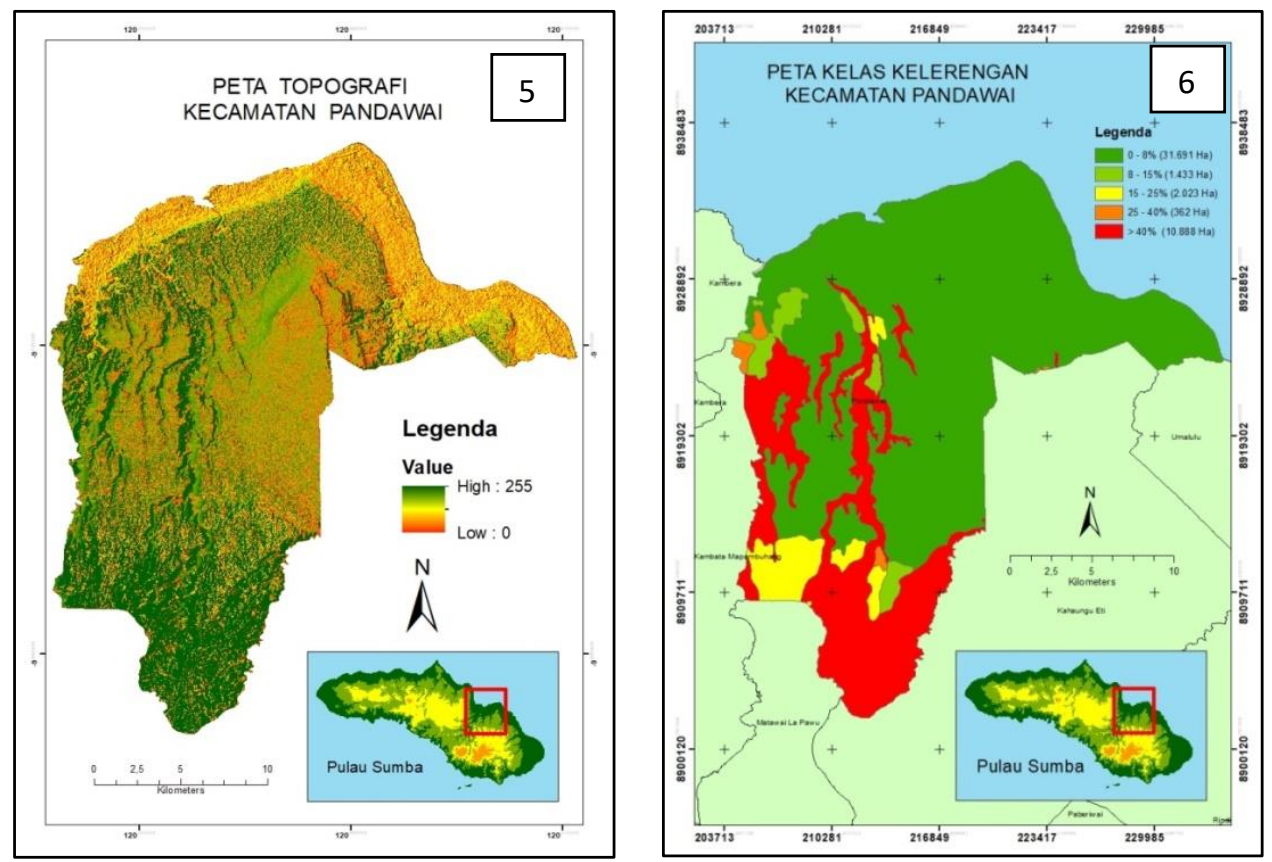

Gambar 5 Peta Topografi Kecamatan Pandawai, dan Gambar 6 Peta Kelerengan Kecamatan Pandawai

Hasil observasi di lapang menunjukkan bahwa padang rumput alam di Kecamatan Pandawai pada umumnya termasuk dalam lahan kering, yang sebagaian besar kurang produktif. Jenis lahan seperti ini dapat dikategorikan sebagai lahan kritis yang membutuhkan penanganan serius terhadap aspek konservasinya. Melalui penggembalaan terkontrol kehadiran ternak dapat menunjang sistem pertanian yang berkelanjutan di lahan kering sebagai penghasil pupuk (Sutaryono dan Partridge, 2002).

Lahan dengan kelerengan $15-40 \%$ diarahkan untuk pengembangan kebun hijauan makanan ternak (HMT). Pada lahan kritis tanaman HMT ditanam rapat dalam barisan sesuai dengan kemiringan lahan. Semakin miring lahan, maka semakin rapat jarak antar barisan tanaman tersebut. Lahan dengan kelerengan lebih dari 40\% masuk dalam kawasan konservasi yang membutuhkan perhatian khusus. Tanaman pakan yang hampir memenuhi kriteria dan umum digunakan sebagai tanaman konservasi adalah lamtoro (Leucaena leucocephala). Jika dibandingkan dengan turi (Sesbania grandiflora), maka tanaman lamtoro lebih lambat dalam pertumbuhannya terutama pada periode anakan (nulik dan Bamualim, 1998). Konservasi lahan dengan menggunakan HMT dapat mengadopsi sistem Sikka, yaitu membuat teras-teras pada lahan yang miring dengan lamtoro ditanam rapat mengikuti kontour tanah. 
Prosiding Seminar Nasional Pembangunan dan Pendidikan Vokasi Pertanian

Politeknik Pembangunan Pertanian Manokwari, 14 November 2020

e ISSN : 2774-1982

\section{KESIMPULAN DAN SARAN}

Penelitian identifikasi padang penggembalaan memberikan informasi bahwa klasifikasi terbimbing dengan alogaritma maximum likelihood tutupan lahan seluas 6.568 hektar merupakan area non padang rumput, sedangkan lahan seluas 39.860 hektar merupakan area padang rumput. Hasil uji akurasi confussion matrix menunjukkan bahwa nilai overall accuracy dari klasifikasi terbimbing maximum likelihood terhadap klasifikasi visual dan ground truth adalah sebesar $91,72 \%$. Kelas kelerengan $0-15 \%$ (datar landai) seluas $33.124 \mathrm{Ha}$, merupakan areal yang ideal untuk dikembangkan usaha budidaya ternak, terlebih bagi pengembangan padang penggembalaan. Lahan dengan kelerengan 15 - $40 \%$ (agak curam - sangat curam) seluas 13.237 Ha baik dikembangkan sebagai kebun Hijauan Makanan Ternak.

\section{UCAPAN TERIMA KASIH}

Terima kasih kami sampaikan kepada Kementerian Pertanian dan SEAMEO SEARCA dan LAPAN Parepare yang telah memfasilitasi peneliti dalam melaksanakan serangkaian penelitian padang penggembalaan di Kabupaten Sumba Timur.

\section{DAFTAR PUSTAKA}

Ahmad, A. (2012). Analysis of Maximum Likelihood Classification on Multispectral Data. Applied Mathematical Sciences, Vol. 6, 2012, no. 129, 6425 - 6436

Bengtsson J., J.M. Bullock, B. Egoh, C. Everson, T. Everson, T. O’Connor, P.J. O’Farrel, H.G. Smith \& R. Lindborg. (2019). Grasslands-more important for ecosystem services than you might think. Ecosphere 10(2):e02582. $10.1002 /$ ecs 2.2582

BPS Badan Pusat Statistik. (2020). Kabupaten Sumba Timur dalam Angka tahun 2020

Cao, J., J.F. Adamowski, R.C. Deo, X. Xu, Y. Gong, \& Q. Feng. (2019). Grassland Degradation on the Qinghai-Tibetan Plateau: Reevaluation of Causative Factors. Rangeland Ecology \& Management, https://doi.org/10.1016/j.rama.2019.06.001

Dirjen Perluasan dan Pengolahan lahan. (2014). Pedoman teknis perluasan areal peternakan. Direktorat Perluasan dan Pengelolaan Lahan. Direktorat Jendral Prasarana dan Sarana Pertanian. Kementerian Pertanian.

ESA. (2020). ESA.int. The European Space Agency.

Hutchinson M. F. \& Gallant, J.C. (2020). Digital Elevation Models and Representation of terrain shape. Terrain analysis : Principles and Apllications, Edited by Jhon P. Wilson and John C. Gallant. ISBN 0-471-32188-5. John Willey and Sons, Inc.

Ibrahim, A., A. Mashaqbah, B. Koch, \& B. Datta. (2020). An evaluation of available digital elevation models (DEMs) for geomorphological feature analysis. 
Enviromental Earth Science 79: 336 Springer-Verlag GmbH Germany, Part of Springer Nature 2020.

Lillesand, T. M \& R. W. Kiefer. (2007) Pengindraan Jauh dan interpretasi citra. Gadjah Mada University Press

Liu,Y., Z. Zhang, L. Tong, M. Khalifa, \& QvWang. (2019). Assessing the effects of climate variation and human activities on grassland degradation and restoration across the globe. Ecological Indicators 106 (2019) 105504

Luque, A., A. Carrasco, Martin, A., \& Heras, A. (2019). The impat of class imbalance in classification performance based on the binary confusion Matrix. Pattern Recognition 91.

McIlroy, R.J. (1976). Pengantar Budidaya Padang Rumput Tropika. Terbitan: Pradnya Paramita.

Newman, S.P. (2003). Maximum likelihood Bayesian averaging of uncertain model predictions. Stochastic Environmental Research and Risk Assessment 17. $291-305$.

Nulik, J. \& A. Bamualim. (1998). Pakan Ruminansia Besar di Nusa Tenggara. Balai Pengkajian Teknologi Pertanian Naibonat dan Eastern Islands Veterinary Servive Project. ISBN 979-95

Ren, J. Z., Z. Z. HuB, Zhao C, J., Zhang B, F. J. Hou, H. Lin L. \& MuB X. D. (2008). A grassland classification system and its application in China. The Rangeland Journal, 2008, 30, 199-209

Sutaryono, Y.A \& I.J. Partridge. (2002). Mengelola Padang Rumput Alam di Indonesia Tenggara. Department of Primary Industries Queensland

Tiscornia, G., W. Baethgen, A. Ruggia, M.D. Carmo \& P. Ceccato. (2019). Can we Monitor Height of Native Grasslands in Uruguay with Earth Observation? Remote Sens. 2019, 11, 1801; doi:10.3390/rs11151801

Watuwaya B. K., J.A. Syamsu, Budiman, \& D. Useng. (2020). Analysis of the potential development of beef cattle in East Sumba Regency, East Nusa Tenggara Province, Indonesia. IOP Conf. Series: Earth and Environmental Science 492 (2020) 012153 The 2nd International Conference of Animal Science and Technology https://doi.org/10.1088/1755-1315/492/1/012153 